\title{
工学寮工学校再考 \\ 構想と実現における山尾庸三とマクヴェインの貢献 \\ RECONSIDERATION OF COMMENCEMENT OF ENGINEERING EDUCATION UNDER THE MINISTRY OF PUBLIC WORKS IN THE MEIJI JAPAN
}

Contribution of Yozo Yamao and C.A. McVean to conceptualization and realization

\author{
泉田英雄*
}

Hideo IZUMIDA

\begin{abstract}
Edmund Morel, the fist chief engineer in railway division of the Meiji Japan, proposed in April 1870 the foundation of the ministry of public works, which consisted of execution, accountants and education sections. The education section's main objective was to train young Japanese under its institute by foreign teachers. The students would learn both theory and practice at its college after they acquired basic knowledge at its school. Although the Meiji government agreed to found the ministry in November 1870, the education section was neglected. Yozo Yamao who trained as engineer at Glasgow, entered the service of engineering section at the Meiji government in 1870, and insisted on the significance of engineering education and survey. When the ministry was officially organized in September 1871, he became a vice minister of the public works as well as chief of both education and survey sections, and assured that he could find and hire foreign teaching staff and build the school buildings before opening of the institute in August 1872. Colin Alexander McVean, a Scottish civil engineer, appointed as a chief surveyor to the survey section, assisted Yamao to build the school facilities and hire foreign staff.
\end{abstract}

Keywords : Engineering Education Section, Engineering Institution, Public Works, Yozo Yamao, Colin Alexander McVean 工学寮，工学校，工部省，山尾庸三，コリン・アレクサンダー・マクヴェイン

\section{1.はじめに}

江戸時代末期、幕府は国防のための軍事技術の導入を図り、オラ ンダの支援によって長崎海軍伝習所、フランスの支援によって横須 賀製鉄所をそれぞれ開設し、日本人技術者の育成にもあたった注 1 )。 しかし、これは民需技術ではなく、日本の本格的技術教育は明治政 府の工部省工学寮の発足を嚆矢とする。工部省は、明治 4 年 8 月 14 日（1871 年 9 月 27 日）、10 寮 1 司の構成で編成され、その 1 等寮の 1 つに工学寮は位置づけられ、公共事業だけではなく各種機械機器 製造のための広範な技術者の育成を担った。その基幹組織である技 術学校は、実社会で活躍できる専門技術者を教育することにし、最 初期には工学校や工部学校と呼ばれ、明治 10 年 1 月に工部大学校と 改称され、明治 19 年 3 月に帝国大学に合併されるまで、多くの工学 リーダーを輩出し、技術立国日本の基礎を築いた注2)。

創設からの歩みについては『舊工部大学校史料』及び『舊工部大 学校史料附録』(ともに 1931 年刊) 注3) にまとめられている。緒言 にあるように「昭和四年六月三日学士会館二於テ小野塚帝国大學総 長、服部五十周年記念誌編纂主任其他古老ノ諸氏ガ、該五十周年記 念誌編纂ニ関シテ会合セル際、(中略) 明治元年ヨリ同十九年迄习第 一期トスルコトノ決定アリタリ」とし、工学寮時代を東京帝国大学
工学部の第一期と位置づけることにしたが、しかし、工学寮創設か らすでに半世紀以上を経ており、同寮に関する一次資料は散逸し、 初期卒業生の記憶や伝聞に大幅に頼ることになった。

上記 2 つの資料を読む限り、工学寮がどのように構想され、実現 したのかについては断片的なことしか分からず、そのため関連史料 を補足し、教育史、政治経済史、科学史などの各方面から解明が試 みられてきた。共通の認識としては工学寮に繋がる工学教育の構想 は、明治 3 年 3 月、鉄道建設技師長エドモンド・モレル (Edmund Morel, 1840 1871）が伊藤博文に出した提案に見いだされることである。 この提案は「建築局」の下に「教導部」を設立するよう提唱し、一 時は省庁再編の嵐の中で立ち消えになってしまうが、モレルの再度 の建言注4) と山尾庸三の尽力により工部省下の 1 寮として工学寮が 創設されることになった注5)。

鉄道寮や灯台寮は工部省発足以前から動き出していたのに対して、 工学寮は測量司とともにまったくゼロからの出発であった。モレル は工部省創設提案書の中で「教導部」の必要性を紙面の半分を使い 力説していることから、その実現にも可能な限り関わったことは想 像に難くない。しかし、明治 4 年に入り結核が悪化し、工部省編成 が成ってから一月半後、同年 9 月 23 日（1871 年 11 月 5 日）に没し、
* 豊橋技術科学大学工学部建築・都市システム学系 博士 (工学)
Dept. of Architecture and Civil Engineering, Toyohashi University of Technology, Dr.Eng. 
さらに 10 月には伊藤博文が岩倉使節団副使として長旅に発つこと になり、山尾庸三に工学寮の体制作りが任されることになった。

工学寮工学校は、既往研究では明治 6 (1873) 年 6 月に都検とし てやってくるヘンリー・ダイヤー（Henry Dyer）によって組織と教育 内容が整えられたと考えられている注 6)。彼は日本の工学教育創設の 最大功労者であることは間違いないが、実際は工学寮発足以前から 山尾庸三のもとで教導部の構想は具体化し、その基幹である附属技 術学校の校舎建設も準備されていた主7)。本稿は、工部省の設置が決 まってからダイヤーが工学校を開学寸るまでの間に、どのようにモ レル提案の教導部構想が具体化し、また、その中心的存在の附属技 術学校が準備されていったのかを明らかにしようというものである。 関連既往研究の論点を整理した上で、「工部大学校関連 2 書」の記述 を太政類典などの公文書と突き合わせ、さらに新たに工学寮及び測 量司の最初期の御雇外国人であるコリン・アレクサンダー・マクヴェ イン（Colin Alexander McVean）の記録注 8) を用いて考察する。

\section{2. モレルの「建築学校」}

明治 3 年 3 月、鉄道建設技師長として雇用されたモレルは、伊藤 博文から近代化の要は何かと訊かれ、「鉄道の建築、道路の補理、海 港海岸の造築、灯明台、礦山等の緒件」を管轄する建築局を設置す ベしと返答した。長官「ミニストル」の下に執事、会計、教導の 3 部門を置き、各部局は暫くは外国人を長とするが、「欧羅巴人の手を 仮らずして事を遂る」ため、教導部は「百般の建築製造に熟練せる インゼニール」を自国で育成する任務が与えられた。教導部の実態 は附属技術学校であり、「十七歳より十八歳位の少年数算測量究理及 外国の語学等略学び得たる」者を「学術大学に送り五六年の間留学」 させることにし、具体的に「東京或いは大阪に於いて、スクウル、 インゼニール建築学校を創立する」ように説いた注 9)。

「スクウル」はschool であり、一方、「インゼニール建築学校」 は engineering college となり、前者は基礎教育の役割を担うものと考 えられる。教育体制については、「学校首長たる者欧羅巴人 2 名日本 人両 3 名蓋し欧人 1 名は学術教導を掌り今 1 人は職業上のことを掌 る日本の教師は只戸外に出職業上のことを教ゆ」とされていた。「学 術教導」とは理論であり、一方「職業上のこと」とは専門実務と考 えられ、いくつの課目をどれだけの学生人数に教えるのかは定かで はないが、5〜6 年間にわたり教師 5 名程が教育を担うことになる。 モレルの「建築局」構想は、「鉄道の建築、道路の補理、海港海岸の 造築、灯明台、磺山等の緒件」といった public works を担う公共事 業局の創設であり、局下の学校は「百般の建築製造に熟練せるイン ゼニール」育成を目的とした engineering college であった。

モレルはこの技術学校構想においていったい何を参考したのであ
ろうか。1 860 年代のイギリス政府にとって、インド省公共事業局に どのようにして大勢の技術者を供給するかが産学界を巻き込んで大 問題になっていた。東インド会社は、1847 年にニューデリー北部の ルールキーにトマソン工学校（Thomason College of Civil Engineering） を開いたが、イギリス流の現場重視の徒弟制技教育を展開できず、 能力のある技術者育成を達成できなかったといわれている。インド がイギリス政府の直接統治下なると、政府はインド省公共事業局の ために本格的な技術者育成に動き出した。土木技術者学会の協力を

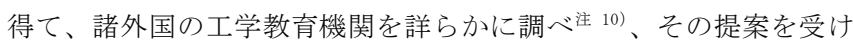
て 1870 年にロンドン北部のクーパー・ヒルに王立インド工学校 (Royal Indian Engineering College、以後 RIEC と略す)を開いた注11)。 これがイギリスにとっての初めての工科大学であり、当時の代表的 技術雑誌『ビルダー（The Builder）』もその設立経緯を数回にわたつ て誌面で紹介しているので注 ${ }^{12)}$ 、モレルはその存在を十分に知って いたと考えられる。 RIEC は基礎学力のある 17 歳から 21 歳の若者 を受け入れ、3 年間にわたり理論と実務を半年ごとに繰り返し学習 した後、 1 年間社会で実地研修を経験し、そしてインド省公共事業 局の採用試験を受けることになる。組織・カリキュラム等に関する工 学校との比較は次稿で議論する。

\section{3.「工部学校」構想}

山尾は他の長州藩士 4 名とともに 1863 年 5 月に日本を発ち、ロン ドンで 2 年間、科学の基礎を学んだ後、ヒュー・マセソン（Hugh Matheson）の紹介で技術の実務訓練を積むためにグラスゴーに向か った。コリン・ブラウン（Colin Brown）に世話になりながら、ネピ ア造船所で徒弟を勤め、不足する理論の学習のために夜学校に通う ことはあっても、大学で工学を学んだのではなかった。イギリスか ら早期に帰国してしまった伊藤とは文通を続け、大政奉還の知らせ を受けると帰路についた。故郷の長州にしばらく腰を落ち着けた後、 明治政府から奉仕の命を受け取り、明治 3 年 4 月 9 日（1870年 5 月 9 日)、民部大蔵省の技術部門の担当となる 注 ${ }^{13)}$ 。

イギリスで 4 年間も生活した体験を持っていたので、鉄道掛雇い のモレルや灯台掛雇いのブラントンは勿論のこと、ヴァルカン鉄工 所（Vulcan Foundry）注 14) に勤めるマクヴェインらともすぐに言葉 を交わすようになったと思われる主 15)。モレルの提案は伊藤博文の 手を経て明治政府に受け入れられ、明治 3 年 10 月 20 日（1870 年 12 月 12 日)、工部省建置が決まった。しかし、卿も大輔も置かず、権 大丞の山尾庸三と井上勝のもとで民部大蔵省から工部省関連部局の 移管は遅々として進まず、そのためモレルは再び 1871 年 1 月 8 日（明 治 3 年 11 月 18 日）付けで「工部省の創立」注 16$)$ を進言し、同省の 編成を促したと考えられる。そこでは、工部省という新しい省庁名

Table 1 初期工部省下の教育機関構想の変遷

\begin{tabular}{|c|c|c|c|c|c|c|c|}
\hline & 明治3年3月モレル「建築局」提案 & \begin{tabular}{|l|} 
明治3年10月20日 \\
「工部省7創置」
\end{tabular} & \begin{tabular}{|l|} 
明治4年4月「工部省学校Э設ク」草 \\
稿
\end{tabular} & \begin{tabular}{|l|} 
明治4年8月14日 \\
工部省組織編成 \\
\end{tabular} & \begin{tabular}{|l} 
明治4年11月4日「工学校定則 \\
概略」
\end{tabular} & \begin{tabular}{|c|} 
明治5年3月2日 \\
「工学校定則ノ禀定」 \\
\end{tabular} & $\begin{array}{l}\text { M6年7月30日工学校略則 } \\
\text { の変更 }\end{array}$ \\
\hline 設置目的 & 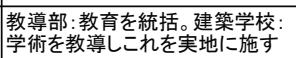 & 記述なし & $\begin{array}{l}\text { 工部学校:開化·富強の基本は人材 } \\
\text { 教育 }\end{array}$ & 工学寮 & 工学寮〉工学校 & 工学寮〉工学校 & 工学寮〉工学校 \\
\hline 学科構成 & 百般の建築製造に熟練せる & & 大学校: 諸工学科技術·活物実地 & & & & 土木，機械，造家を含む7科 \\
\hline 学校組織 & スクール(略学)と大学校 & & スクールとコウレージ & & 大学小学ノ2校卜ス & & 大学校 \\
\hline 教員組織 & $\begin{array}{l}\text { ヨ一ロッパ人2名(学術と職業), 日 } \\
\text { 本人1名(戸外職業) }\end{array}$ & & $\begin{array}{l}\text { 西洋人教官、小学校(7人), 大学校 } \\
(6+6 \text { 人) }\end{array}$ & & \begin{tabular}{|l} 
西洋人教官、生徒20人/教員、 \\
都検
\end{tabular} & & 都検ダイヤーを含む9人 \\
\hline 入学年齢 & スクール(17-18歳) & & 小学校(16歳以下,300人) & & 小学(13-17,定員300人) & & \\
\hline 修業年限 & 大学校(5-6年) & & 小学校2年程 & & 小学校(4級2年)と大学校(4級) & & 6力年 \\
\hline 備考 & & & |他に質問及傳習生の制度 & & 小学校明治5年7月15日開校 & & \\
\hline
\end{tabular}


に合わせて、組織は技術局、俗務及び会計局、教導局に改称しただ けで先の提案がくり返されている。このようにモレルは教導を重視 し、それを伊藤と山尾が受け止め、『旧工部大学校史料』では「伊藤 博文及山尾庸三八先ヅ学校ヨ建設シテ多数ノ人材 7 養生スルニ若カ ズトナシ、明治四年辛末四月工部学校ノ建設ニツキ工部省へ」建議 したとされる。この「建議」の後に、同じく明治 4 年 4 月付の「質 問及傳習生」、「質問並傳習生規則」、「部学校建設概要」が続き、 一気に教導局構想が具体化した注 ${ }^{17)}$ 。そして、教導局は本格的技術 者養成を国内で行う工部学校と、実務を中心にした短期海外研修制 度を司ることになった。伊藤は明治 3 年 11 月から翌年 5 月まで日本 を留守していたから、山尾が主導して作成したのであろうか。

この建議と建設概要は、太政類典の明治 4 年 7 月付「工部省学校 ヨ設ク」注 18 ) 文書に、校舎建設用地として延岡藩邸を収用寸る旨の 文書とともに収められている。工部学校の内容を見ると、お雇外国 人に代わる日本人技術者を養成することを目的にし、「スクール」で 基礎を修得させ、さらに「コウレージ」で専門の学術と実務の両面 を学習させることにし、モレルの「建築学校」構想がそのまま継承 された。新たに付け加わった点は、教員構成と学生定員が示されて いることで、それが決まれば校舎規模も確定することになり、校舎 と寄宿舎の略図も準備されていた。小学校は 7 名の教員数に対して 300 名の生徒定員数としているが、大学校は教員構成を教師と助教 師それぞれ 6 名と寸るだけで、生徒数は明示されていない。「学力ノ 検查ヨ経テ試程ヨ超エル者」だけを大学校に入学させ、その者を「諸 工学科技術二涉リ活物実地ノ修行」というのであるから、少数の優 秀生徒を教員 2 名が一組になり 6 つの学科に分けて理論と実務をそ れぞれ教えることになる。さらに、雇用予定の教員数と給料、建設 予定の建物種類と建設費が算出されており、教師団任用の見通しが あったからこそ工部学校建設に動き出したのであろう。

以上、この建議は、スクールとコウレージという英語が使われて いることから分かるように、英語文からの訳文であり、モレルがこ の文書作成にも関わったと考えられる。おそらく山尾は工部大丞と して全幅の支援をしたと思われるが、モレルが志半ばで亡くなり、 技術学校構想がどのようにして具体化されたのか定かではない。

\section{4.「工学寮工学校」}

明治 4 年 8 月 14 日 (1871 年 9 月 29 日)、工部省は 10 寮 1 司によ つて編成され、その 1 つに工学寮が位置づけられ、山尾が工部大丞 及び工学頭兼測量正に就任した。工学寮は前述したように技術学校 とともに留学研修制度をも管轄し、同時に設置された測量司と組織 的には一体化していた。山尾自身、工部省編成前にこの 2 つ部局 の重要性を十分に認識していたが、自らは造船製作分野の長を希望 していた注 ${ }^{19)}$ 。おそらくこの新設の 2 つの部局を司る適当な人物が 見つからなかったため、自ら兼務することにし、当座、1つの事務 体系で運営することにしたのであろう。両部局の立ち上げに最初か ら関わっていたのが測量師長として任用されたマクヴェインで注 20)、 任用の時から業務を簡便に日記に書き留め始めた注 21$) 。$

明治 5 年 3 月 2 日（1872 年 4 月 9 日）付けで山尾は「工学校定則 ノ概略」注 22) を告知し、そこでは工部学校ではなく工学校と呼び、 工学寮下の学校であることを宣言した。先の「工部省学校习設ク」 と比較すると、開校を明治 5 年 7 月 15 日（1872 年 8 月 18 日）時期
とすること、小学校と大学校ともに 4 級・ 2 年とし、大学校課程を 4 あるいは 5 試で終了した者には留学の機会を、6 試の者は内国工場 に就職させることとした。この級とは半年を 1 期とする学期制のこ とで、それぞれの学期末に生徒に試験が課され、それに合格すると 昇級することになっていた。学術と実務を学び、成績優秀者は海外 でさらなる実務経験を積むことになり、大学校教員構成については 触れられていないものの、基本的には「工部学校建設ノ議」を踏襲 しているといえる。

このように、モレルの建築学校構想は工部学校を経て工学校とい う名称で固まり、あとは教師団任用と校舎建設を進めるだけであっ た。校舎建設に関しては、後述するようにマクヴェインの指揮によ り開始された。教員雇用に関しては、明治 5 年 2 月 12 日（1872 年 3 月 20 日）付けで太政官宛に「工学勧工都検ノ者御雇入他儀伺」をた て、都検 1 名と小学校教師 6 名の任用が許可されていた注 23$)$ 。とこ ろが、イギリスから招致したはずの教師団の到着が遅れることがわ かり、小学校の開校が 2、3 月遅れることを太政官に申し入れた。

\section{5.マクヴェインとは}

マクヴェインは、ブラントンを技師長とする灯台建設技術者団の 一員として幕末日本にやってきた。神子元島での灯台建設作業は過 酷を極め、ブラントンの指揮のもとで業務を続けることは困難とし て、着任一年後の明治 2 年 7 月 25 日（1869 年 8 月 26 日）、燈明台 を辞職してしまう注 24)。日本での鉄道建設を見越してヴァルカン鉄 工所が横浜に進出してきており、そこに職を得て、家族ともども日 本に留まることにした。山尾の名前はマクヴェインの日記や手紙類 に頻繁に見いだすことができ、彼の父からの 1870 年 11 月 15 日（明 治 3 年 10 月 22 日）付け手紙が現時点で確認できる限り最初のもの である注 ${ }^{25)}$ 。彼の父は、山尾という人物についてグラスゴー在住の コリン・ブラウンに照会したところ、「明治政府のリーダーにふさわ しい人物なので、彼に会いに行き、ぜひ仕えるように」と息子に助 言した。そうすると、1870 年半ば頃にはマクヴェインは山尾と出会 い、その人物にいたく関心を持つようになり、父にそのことを知ら せたと考えられる。その後 2 回、山尾を支えるよう父から手紙が届 き、マクヴェイン日記では 1871 年 9 月 13 日（明治 4 年 7 月 29 日） 付けで工部省雇いになり、3 週間程後に測量司測量師長に任用され たことになっており、日本側資料と合致する。

このブラウンはヒュー・マセソンの友人であり、2 カ年に渡る山 尾のグラスゴー生活を支えてくれた人物である注 26)。一方、マクヴ

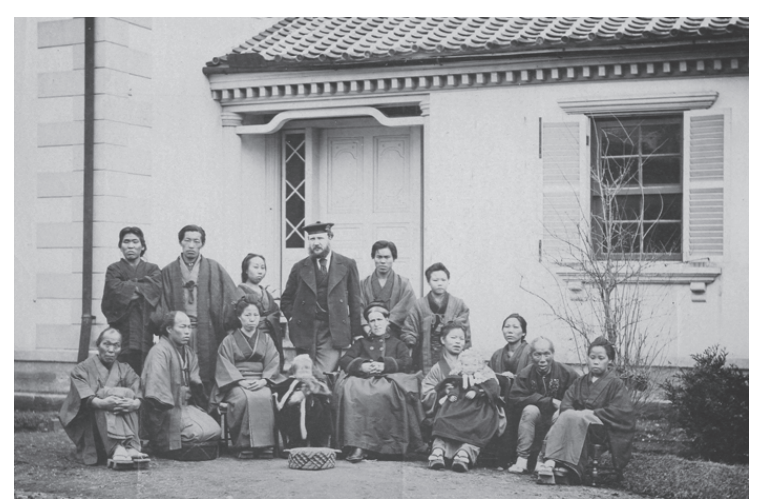

Fig. 1 McVean Family at Yamato Yashiki, $1872 \odot$ McVean Archives 
Table 2 マクヴェイン記録と対比したエ学寮関連年表

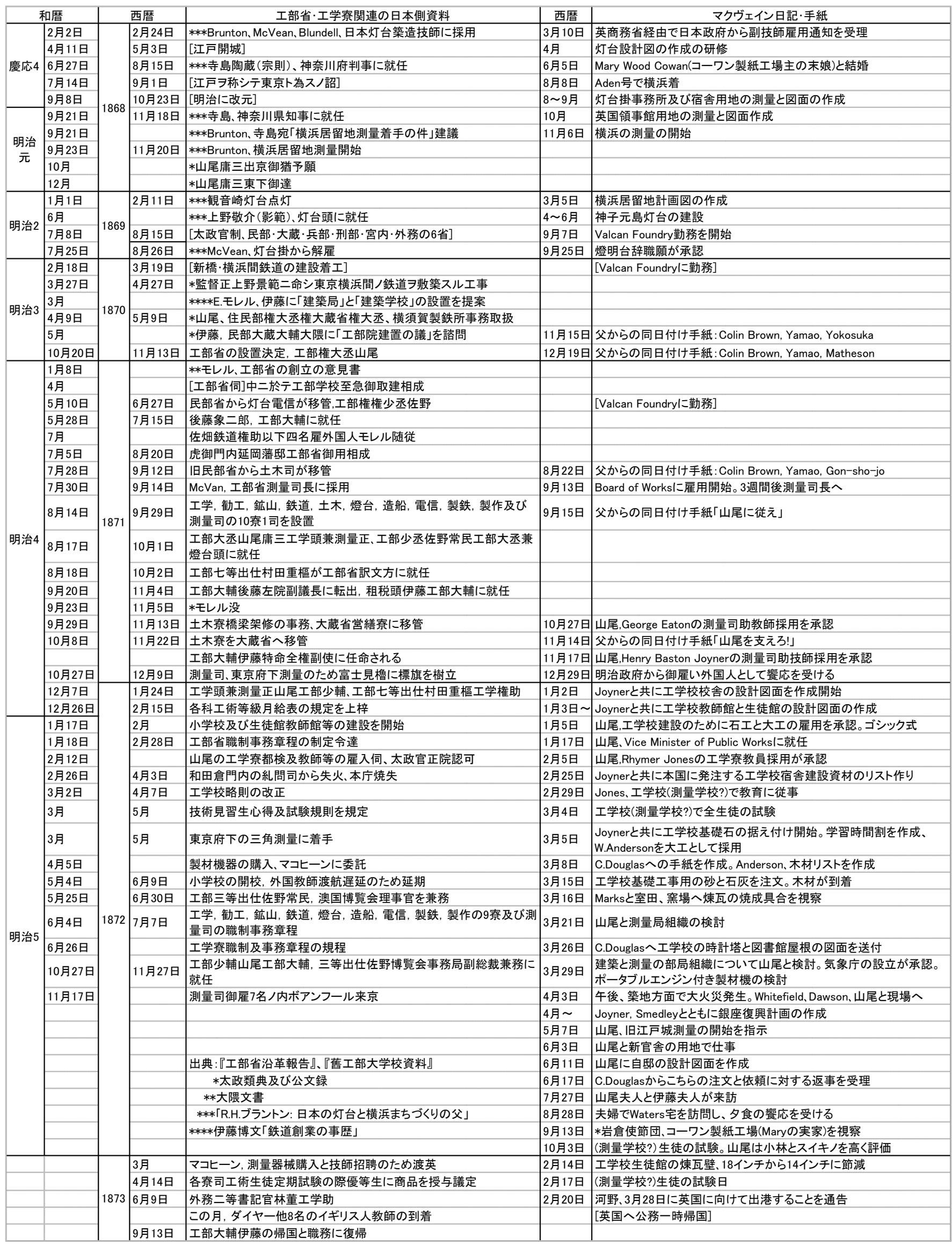


エインの父はエジンバラ大学で哲学を修めた後、聖職に就き、終生 アイオナ大聖堂の司教を勤めた。その長男として生まれたマクヴェ インは 13 歳でエジンバラの公学校に入り、卒業とともに土木技術者 の道を歩从始める。いくつかの土木技師事務所で実務研修を受け、 その後測量を中心にした業務を経験した注27)。1 865 年から 2 年間、 ブルガリアで鉄道建設に従事し、同時代の多くのイギリス人技術者 と同じょうに海外志向をもっていたのであろう。灯台建設技術者と して日本政府の任用が決まると、コーワン製紙所有者の末娘メアリ 一（Mary Wood Cowan）と結婚し、これが彼の人生の大きな転機と なった。メアリーの長兄チャールズは工場経営と共に貴族院議員を、 別の兄ジェームスはエジンバラ市長（1872 74）をそれぞれ勤め、 姉の一人は大出版社のトーマス・カンスタブル（Thomas Constable） 注 28) と結婚し、また別の姉の娘はグラスゴーの建築家キャンベル． ダグラス（Archibald Campbell Douglas）注 29) と結婚していた注 30)。

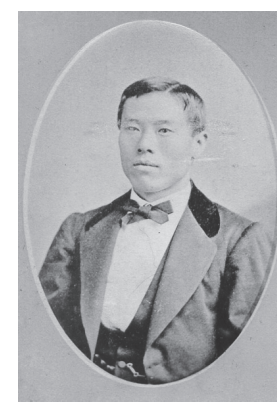

Fig. 2 Ito

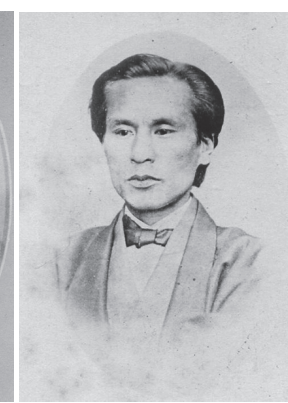

Fig.3 Yamao

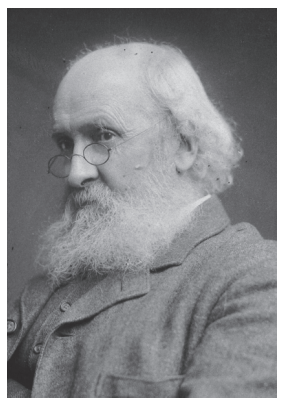

Fig.4 Campbell Douglas

\section{全て○McVean Archives}

\section{6. マククヴェイン関与の可能性}

妻のメアリーは姉妹・親戚と頻繁に文通をしており、マクヴェイン が職務上の問題があればコーワン家を頼って支援を受けることがで きたはずであるが、これについては現時点の関係資料解読では断片 的なことしか分からない。まず、義兄のカンスタブルは、19 世紀半 ばグラスゴー大学の初代工学教授であったルイス・ゴードン（Lewis D. B. Gordon）とは公私にわたる付き合いがあり、彼の逝去に際して 『ゴードン回想録』を上梓している注 ${ }^{31)}$ 。同回想録の中にヒュー・ マセソンからの興味深い追悼文が寄せられており、要約するとマセ ソンは、1872 年に旧知の日本人の中で工部大臣となった人物から技 術学校設立の協力を求められ、最も信頼できるゴードンに相談した が、すでに彼はグラスゴー大学を辞していたので、代わりに同大学 後任教授のウィリアム・ランキン（William J. M. Rankine）が紹介さ れたという内容である注 ${ }^{32)}$ 。

マセソンは 1882 年の Ross shine Journal 誌にも同じことを述べて おり 注 ${ }^{33)}$ 、明治 5 年 8 月 (1872 年 9 月頃)、伊藤博文が岩倉使節団副 使として訪英した際に実際にマセソンに依頼したのであろう。しか し、すでに前年に出されていた「工部省学校习設ク」と「工学校定 則ノ概略」の中では学校の規模と課程がほぼ定まり、明治 5 年 2 月 12 日（1872 年 3 月 20 日）には教師団の任用に目処がたち、明治 5 月 7 月 15 日（1872年 8 月 28 日）に開校することになっていた。そ う寸ると、伊藤が明治 5 年 8 月にマセソンに会って、初めて技術学 校教師団の雇用委託をしたのではなく、少なくともその半年前に委 託していたことになる。あるいは、伊藤＝マセソンとは別のチャン
ネルがあったのかもしれない。

RIEC の創設に際して、エジンバラ大学のジェンキン（Fleming Jenkin）とグラスゴー大学のランキンが調查委員会委員に選ばれ、 この 2 人が 1860 年代のイギリスの工学教育に関して最も高い見識を 持っていた。ランキンに依頼される前に、どのようにして技術学校 の規模と課程が決められ、さらに校舎と寄宿舎の建築略図面が作成 されたのであろうか。この点に関してマクヴェインの関与は現時点 では明らかではないが、岩倉使節団が 1872 年 9 月にエジンバラのい たるところで大歓迎を受け、またコーワン家では製紙工場の視察後、 驚くほど盛大な昼食会が催されたのは、まったくマクヴェイン夫妻 のお陰であった注 ${ }^{34)}$ 。また、後述するようにグラスゴーのダグラス は工学校校舎他の建設資材を日本に送り、さらに「腕利きの若い建 築家」を派遣したことを考えると、彼が事前に略図面を提供し、マ クヴェインと山尾を助けていた可能性は否定できない。

\section{7. 工学寮小学校校舎の建設}

小学校校舎と寄宿舎は、その年の暮れからマクヴェインの指揮で 実施設計業務が始まり、そこでは明治 4 年 7 月の「工部省学校 7 設 ク」に添付された略図面がもとにされたのであろう。外国人教師任 用と建物工事のための莫大な予算措置が必要であり注 35 )、明治 4 年 8 月 14 日の工部省編成の完了を待って、まず技術職員の任用から着手 した。山尾とは週一回以上顔を合わせ、伺いを立てながら 1871 年 10 月 27 日 (明治 4 年 9 月 14 日)にジョージ・イートン(George Eaton) 注36）を測量教師に採用し、また 1871 年 11 月 17 日（明治 4 年 10 月 6 日）に測量と図面作成に長けたジョイナー（Henry Baston Joyner） 注 37) を鉄道寮から転属させ、二人で東京府下測量の準備と工学校の 実施図面作成に当たった。

1872 年 1 月の日記を見ると、ジョイナーが校舎と生徒館、マクヴ エインが教師館の製図を分担し、1872 年 1 月 5 日（明治 4 年 12 月 6 日）には煉瓦造の設計案を山尾に示し、そして石工と大工の職長を 任用する了解を得た。校舎はゴシック様式になることが決まってお り、1月 20 日（明治 4 年 12 月 11 日）にはマークス（James Marks） 注 38) とアンダーソン（William Anderson）をそれぞれ石工頭と大工頭 に、またジョーンズ (Richard Oliver Rymer Jones) ${ }^{\text {注 }}{ }^{39}$ をを測量教師に、 さらにウィルソンを測量師にそれぞれ任用の伺いをたてた主 ${ }^{40)}$ 。マ クヴェインはできる限りすでに鉄道や灯台の建設に雇われている技 術者・技能者を転属させ、どうしても適任者がいない分野では自らの チャンネルでイギリスから呼び寄せた注 ${ }^{41)}$ 。測量ではイギリス海軍 水路測量部での同寮であったシャボー（Henry Scharbau）注 42) を、 建築ではダグラスを通じてボアンヴィル（Charles Alfred Chastel de Boinville）注43)を呼び寄せた。

『工部省沿革報告』では、「明治五年正月造営掛ヨ置キ雇英人「ア ンデルソン」フ造家師トナシ小学校及ヒ生徒館教師館等 7 経始ス」 注 44) とあるが、アンダーソン着任の 2 ケ月前にマクヴェインらによ り実施設計業務は始まっていた。また、『明治工業史 建築編』には 設計がマクヴェインによってなされ、さらに小学校の時計塔の煉瓦 がイギリスからの輸入品であることの伝聞が寄せられており、これ はマクヴェインの記録と符合する。

2 月 25 日（明治 5 年 1 月 17 日）には小学校校舎の建設資材リス トができあがり、グラスゴーのダグラスに資材調達の仲介を依頼し 


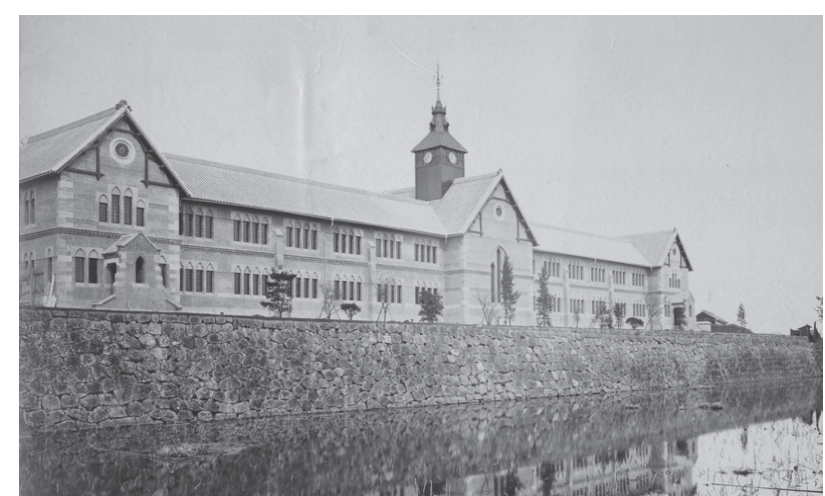

Fig.5 "Engineering School designed by H.B. Joyner, and erected

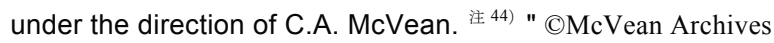

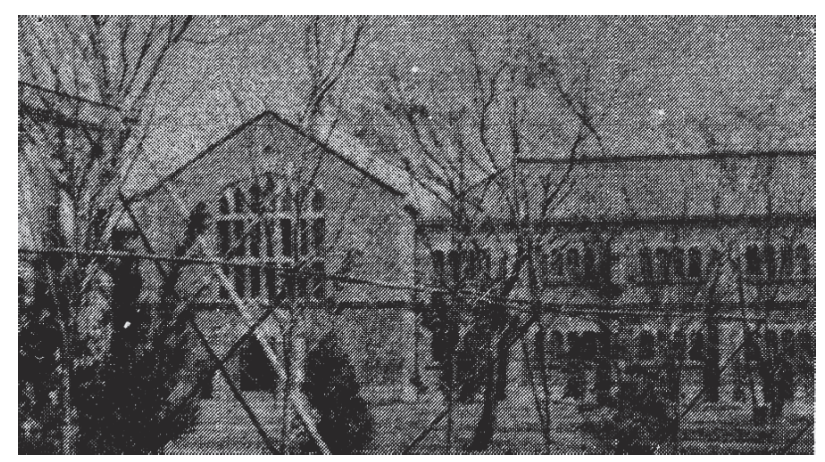

Fig.6 生徒館 出典: 『舊工部大学校史料』

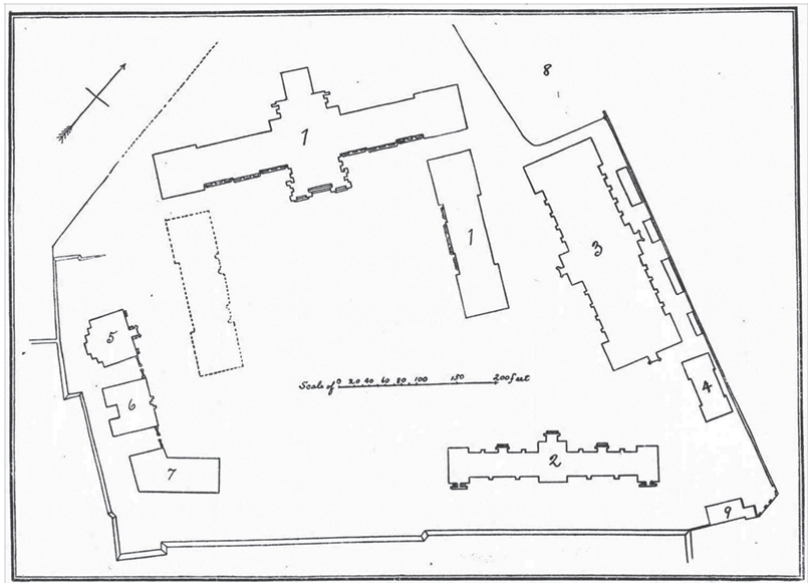

Fig.7 校舎配置図 出典: Imperial College of Engineering Report, 1877。建設は小学校校舎(2)から、生徒館(3)、教師館(3)の順で進んだ。

た 注 ${ }^{46)}$ 。時計塔と図書室小屋組の図面をひく一方で、3 月 5 日（明治 5 年 1 月 26 日）に基礎工事に着手し、耐震性を高めるために煉瓦壁 に Hoop Iron を敷くことにし、数回にわたって Hudson Malcolm \& Co. 社に大量に注文した注 ${ }^{47)}$ 。マークスが煉瓦焼成を、アンダーソンが 木材の加工を担い、小学校校舎建設を急いでいたが、その後に生徒 寄宿舎と教師宿舎の建設工事が控えており、3 月 25 日（明治 5 年 2 月 29 日）時点で、マクヴェインは山尾に対して工学寮教師団が来日 する 8 月までに宿舎完成が間に合わないので、臨時の宿舎を用意す るように進言した注 48 。これは明治 4 年 11 月 4 日（1871 年 12 月 15 日）付の「工学校定則ノ概略」と合致し、そこで述べられたように 小学校を明治 5 年 7 月 15 日（1872 年 8 月 18 日）に開校させるため
に教師団雇用の手配を行い、た施設建設を進めていたことになる。 実際は、 7 月の教師団来日はかなわず、また施設建設工事も大幅に 遅れていた注 49)。

マクヴェインは、小学校校舎・宿舎の他に測量司や勧工寮などの施 設建築の設計と建設を担い、また測量事業の開始準備をしなければ ならず、多忙の中、後述するように、さらに 1872 年 4 月 3 日の銀座 大火の後、山尾の指示により復興計画作りに約 3 週間集中すること になった。その後、小学校校舎·宿舎建設を再開し、5 月20日（明 治 5 年 4 月 13 日)、横浜のウィットフィールド・ドーソン事務所注 50) から携帯型蒸気エンジン鋸の購入を決めた。イギリスからの建設資 材の到着が遅れたことや、フィート単位と尺単位を取り違えたため に工事のやり直しがあったが、小学校校舎は 1872 年暮れにほぼ完成 し（Fig.5）、次いで生徒寄宿舎の建設に着手する。1873（明治 6) 年 2 月 14 日のマクヴェイン日記では、寄宿舎建物のマリオンを煉瓦造 に、また壁厚を 18 インチから 14 インチに減ずることにしたとあり 注 51)、工費と工期を切り詰めようとしていたと考えられる（Fig.6）。

『明治工業史 建築編』によれば、生徒館（生徒寄宿舎）は明治 6 年 8 月 10 日起工、明治 7 年 9 月 30 日竣工となっており、マクヴェ インが留守の間、ボアンヴィルが設計監理、アンダーソンが木工事、 マークスが石工事をそれぞれ担当し、並行して教師館の工事も行っ ていたと考えられる（Fig.7）。1872 年初めから山尾に対して測量と 気象観測の機器購入のために一時帰国を願い出ており、1873（明治 6）年になってやっとかない、同年 3 月 28 日に河野通信を引き連れ 離日寸ることになった。

\section{8. 工学寮及び測量司}

前述したように、1872 年 4 月 3 日（明治 5 年 2 月 26 日）に銀座 一帯が焼失し、同年 4 月 5 日、山尾の指示でマクヴェインらは復興

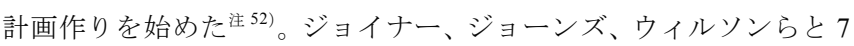
日間で測量を終え、またスメドレー注 53) を呼び寄せて建物の設計図 面を描かせ、さらにジョイナーと 2 人では街路配置図を作成した。 復興計画案をまとめると、村田文夫注 ${ }^{54)}$ に翻訳させ注 ${ }^{55)}$ 、 4 月 21 日 (明治 5 年 3 月 14 日)、工部省でその説明を行ったが、その後どう なったのかについては日記に記述はない。いわゆる銀座煉瓦街計画 に関する既往研究注 56) と合致する内容であり、付け加えるとすれば、 焼失地区を実測調查した上で街路計画と建物計画を作成したのは唯 一マクヴェインらであり、ウォートルスとブラントンの案は概念的 なものにならざるを得なかった。

工部省は、明治 4 年 8 月 14 日に 10 寮 1 司の構成で動き出したが、 同年 10 月 8 日にはその 1 つの土木寮を大蔵省に移管させてしまい、 明治 5 年 1 月 18 日に令達された工部省職制事務章程では 9 寮 1 司と なり、社会基盤や公共建築の営繕を担当する部局はなかった。銀座 大火の後、山尾は工学寮及び測量司の長として復興計画に関わる必 要はなかったはずであるが、工部少輔の責務としてどうしても自ら の指揮下の職員を総動員してやらなければならなかったのであろう。 明治初期におけるこのような土木と営繥に関わる工部省と大蔵省の ぎくしゃくした関係は、今後もっと解明されるべきことである。銀 座復興は、山尾の命を受けマクヴェインは部局内外の技術者の力を 借りて 2 週間余りで計画案をまとめ上げ、実施は叶わなかったが、 大部分は大蔵省のウォートルスに引き継がれたと考えられる注 57 。 
工部省はモレルの Public Works の構想をもとに発足したにもかか わらず、編成過程の中でその中心部局の土木と営繥を失い、役割を 新技術の導入に比重を移してしまうが、では、モレルの教導部と建 築学校の構想はそのまま工学寮と工学校として実現したといえるの であろうか。教育体系は、その変遷を見る限り、小学校で基礎を修 めた後、大学校で外国人教師によって理論と実技の両方を学ぶこと になっており、就業年数に若干の差異は見られるが一貫性が存在す る。また、学科制は工部学校構想になってはじめて登場し、工学校 に引き継がれ、教育体系はしだいに具体化する過程が読み取れる。 しかし、組織機構を見ると、モレル提案の教導部は、建築局長官「ミ ニストル」下の 3 部門の 1 つであったのに対して、工部省下の工学 寮は他の現業部門と同列に位置づけられてしまった（Fig.8）。

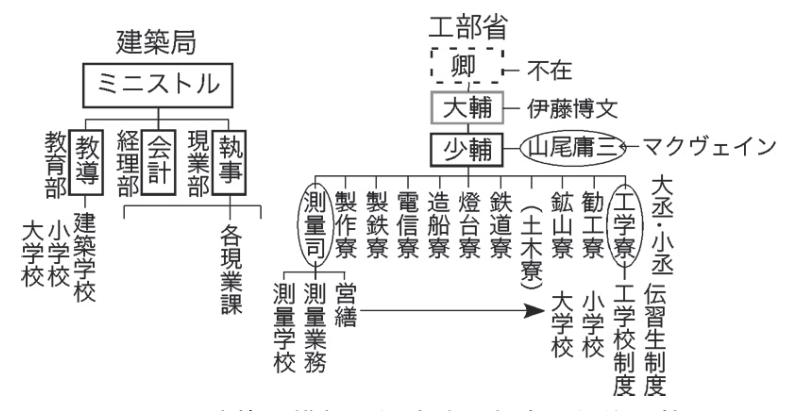

Fig.8 モレルの建築局構想と編成時工部省の組織 楕円は山尾管轄

モレルが教導部を重視したのは、前年にイギリス政府がインド省 下に RIEC を発足させたことや、諸外国の工学教育事情を参考にし たと考えられる。工部省が卿を持たず、組織編成にイニシアティブ をとる人物がいなかったことも原因の一つと考えられる。大輔の伊 藤博文は多忙であり、少輔の山尾が工部省の中に工学寮と測量司を 新設させた以上、自らが両部局の長も兼ね、マクヴェインの助けを 借りながら営絟業務を遂行することになった。明治 5 年 6 月 26 日 （1872 年 7 月 31 日）になってやっと各寮司の職制事務章程及び工 学寮及測量司分課処務規程が定められたが、その中でも工学寮と測 量司は一体化され、測量司が営繕を担うことになっていた注 ${ }^{58)}$ 。そ のため、その年の暮れにやってきた建築家ボアンヴィルは手続き上 測量司雇いとされ注 59)、この体制は明治 7 (1874) 年 1 月 9 日に測量 司が内務省へ移管されるまで続いた ${ }^{\text {注 }}{ }^{60)}$ 。

\section{9. まとめ}

工学寮は、モレルの建築局構想の中の教導部を実現に移したもの であり、お雇い外国人技術者に代わって各種近代化事業を担う日本 技術者を育成することを目的にしていた。育成の中心は技術学校で あり、基礎教育の小学校と専門教育の大学校の 2 校から成り、専門 教育は理論と実習によって修得すべきとされた。教導部は、明治 3 年 10 月 20 日の工部省建置が決まった際には除外されていたが、明 治 4 年 4 月に山尾庸三が明治政府に技術学校の必要性を説くととも に、開設のための組織、予算、施設略図面を含んだ具体的計画案を 提示し、明治 4 年 8 月 14 日の工部省編成において 10 寮 1 司の 1 つ として工学寮設立が認められた。

工学寮は本格的技術者養成の工学校制度と速成の伝習生制度を持 ち、前者の開学準備を急務とした。山尾の明治 4 年 4 月の工学校計
画案では、小学校教師団雇用と施設建設の見通しが立ち、明治 5 年 7 月に開学することになっていた。前者の教師団についてはどのよ うなチャンネルで採用しようとしたのかは不明であるが、後者の校 舎他の建設については測量司最初の御雇技術者であるマクヴェイン に大きく頼ることになった。

マクヴェインは山尾を支え、工学寮施設の営繥と測量司の立ち上 げに尽力し、自らのチャンネルで測量技術者、測量学校教師、営䋨 建築家を雇用し、さらにグラスゴーの建築家であるキャンベル・ダ グラスから資材購入の仲介を受け工部小学校教校舎、生徒館、教師 宿舎の建設を竣工させた。

大学校は教師と助教師をそれぞれ 6 名雇用することになっていた ので、6 学科制を想定していたと考えられる。1860 年代、イギリス 産学界ではインド省公共事業省技術者育成をめぐって技術者教育が 大きな議論を呼び、グラスゴー大学をはじめとして工学部創設の動 きがあった。結局は、1871 年に技術者教育を独占的に行う王立イン ド工学校が設立されるが、この間の議論は当時の技術雑誌に逐次紹 介された。『ビルダー』誌は、1871 年の時点で学科制により理論と 実技をバランスよく教育するチューリッヒ大学のアドバンテージを 主張していた。このような議論を、モレル、山尾、マクヴェイン、 ダイヤーなど、明治日本の技術学校創設に関わった人物も十分知っ ていたと考えられ、その検討は次稿に譲る。

\section{謝辞}

マクヴェインの子孫である Andrew and Anne McVean 夫妻、Colin McVean Huston 氏、Michael McVean Gubbins 氏、またボアンヴィル の子孫である Simon Chastel de Boinville 氏から貴重な資料を提供い ただき、また元エジンバラ市歴史建造物監查官 David Walker 氏と元 スコットランド都市計画家協会会長 Kelly Roger 氏には適切なる助 言をいただいた。ここに記して謝意を表するとともに、2011 年東日 本大震災の復興事業遂行のため執筆発表が大幅に遅れたことをお詫 びいたします。

\section{参考文献}

1）三好信浩：日本工業教育成立史の研究--近代日本の工業化と教育，風間書 房, 1979。

2）舊工部大学校史料編纂會：舊工部大学校史料及び舊工部大学校史料附録, 虎ノ門會発行，1931。同書は，旧工部大学校史料編纂会『旧工部大学校史 料・同附録』として青土社より 1978 年に復刻再版された。当初版は国会図 書館近代デジタルライブラーで閲覧可能である。

3）兼清正徳：山尾庸三傳-明治工業立国の父-, 山尾庸三顕彰会, 2003。

4) The Chronicle and Directory of China, Japan and the Philippines for the year of 1871, 1872, 1873. C \& D year と訳す。

5）工学会：明治工業史 建築編，工学会，1927。

6）大蔵省：工部省沿革報告, 大蔵省，1889。

7）柏原宏紀：工部省の研究，慶応義塾大学出版会，2009。

注

注 1）参考文献 1）の第 1 編（1 177 頁）に幕末の幕藩の近代技術導入及び教 育がまとめられている。個々の事例について、長崎海軍伝習所については、 ファン・カッテンディーケ: 長崎海軍伝習所の日々（東洋文庫 26, 平凡社, 1964）、横須賀製鉄所については、勝安芳編輯 : 海軍歴史，巻 25 (海軍省, 1889）に詳しい。

注 2）このような評価は、参考文献 1）の第 2 編（228 頁）他、清水慶一：工 学寮・工部大学校に於ける建築教育について (国立科学博物館研究報告 $\mathrm{E}$ 類 8，25 35 頁，1985）、大淀昇一：明治期日本における先導技術者養成機関 の意義と変容（1）（島根大学教育学部紀要 21 巻, 32 54 頁, 1987）、柿 
原泰：工部省の技術者養成（鈴木淳編：史学会シンポジウム叢書 工部省と その時代，山川出版社，57 82 頁，2002）、加藤詔士：日本・スコットラ ンド教育文化交流の諸相-明治日本とグラスゴウー (名古屋大学大学院教育 発達研究所紀要, 第 56 巻第 2 号, 2 39 頁, 2009) 、和田正法 : 工部大学 校創設再考（科学史研究 50, 山川出版会, 86 96 頁, 2011) に共通する。 注 3）参考文献 2)

注 4）大隈文庫 : 工部省所局諸掛二関スル意見書 / 鉄道局機械方長モレル, 明治四年一月八日（早稲田大学古典籍総合データベース）。

注 5) 拙稿: 工部省創設再考, 日本建築学会計画系論文集 80（708），411 417 頁, 2015。

注 6）植村正治：明治初期工学教育機関の創立-工学寮について-（社会科学 89, 同志社大学, 21 29 頁, 2011）。本論文は、ダイヤー就任前の工学寮 の役割について教育史から分析している先行研究の 1 つである。

注 7) 本稿は、拙稿"Inquiry in Organization and Campus Buildings for the Imperial College of Engineering" (Proceeding of the 21th IAHA Conference, Singapore, 18p, 2010）を書き改めたものである。

注 8）Colin Alexander McVean, 1838 1919. 自らの略歴を次に発表している。 - Colin Alexander McVean, Celtic Monthly, December 24, 1896.

· Colin Alexander McVean: Little Journal: Griffis Collection, Rutgers University. ·彼が亡くなる時、財産を子供たちに平等に資産を分け与えといい、手紙や 絵画類は長男、日記や写真類は末娘がそれぞれ相続したが、その他は不明。 日記はマクヴェイン専らのものと夫婦で書いたものの 2 つが存在する。手 紙類はマクヴェインが家族親類縁者から日本で受け取ったものしかなく、 業務書類は一切発見されていない。現在は末娘の親族が McVean Archives として保管している。

注 9）伊藤博文：鉄道創業の事績（澤和哉編：鉄道一明治創業回顧談, 築地 書館, 47 51 頁, 1981)。

注 10) Council of the Institution of Civil Engineers, The Education and Status of Civil Engineers, in the United Kingdom and in foreign countries, Institution of Civil Engineers, London, 1870.

注 11) Brendan Cuddy and Tony Mansell: Engineers for India: The Royal Indian Engineering College at Cooper's Hill, History of Education, vol.23, no.1, pp.107 123, 1994。

•グラスゴー大学のランキン教授 (John William Macquorn Rankine, 1820 72) とエジンバラ大学のジェンキン教授（Flemming Jenkin, 1833 85） が深く関 わっていたことが知られている。

注 12) Civil Engineering College in India, The Builder, Feb.4, pp.77 78, 1871.

注 13）毛利藩主より明治元年十月「山尾庸三出京御猶予願」が、同年十二月 に「山尾庸三東下御達」（公文録：国立公文書館）が太政官宛に出されて いるが、そのまま明治政府出仕とはならず、「山尾庸三」（太政官履歴原 書 : 国立公文書館）では山尾の奉職は明治三年四月九日民部権大丞兼大蔵 権大丞から始まる。コリン・ブラウンへの手紙では Gon-sho-jo（権少丞）と して任用されたことを伝えており、食い違いが見られる。

注 14）Vulcan Foundry はイギリスのランカシャーに工場を置く蒸気機関車製 造会社で、19 世紀後半国内外に広く蒸気機関車を販売した。

注 15）大隈文庫：造幣局 $コ$ 工部院内移管反対意見書、年号不詳（早稲田大学 古典籍データベース)。

·本文書の後半で、外国人技術者の勤務を厳格に規定す心゙きこと、また山尾 庸三、井上勝、塩田三郎らを工部院執行各局の長候補として進言しており、 御雇外国人や日本人技術官僚らをよく知っていた。柏原氏が想定するよう に、このようなことが可能なのはモレルしかなく、彼が明治 3 年 7 月頃に 作成したと考えられる（参考文献 7） 25 頁）。

注 16）大隈文書: 1871 年 1 月 8 日工部省ノ創立 大隈宛/エドワルト・モレル、 (早稲田大学古典籍総合データベース)。

・エドワルトと執筆者名に誤謬が見られる。

注 17）参考文献 1）4 6 頁。この 4 文書とも辛未四月工部省とあるだけで執 筆者名は不明である。「建議」の最後は「工部学校至急御取建相成」と結 んでいるのであるから、その後には質問並傳習生の文書ではなく、「工部 学校建設概要」が続くべきである。4 文書は 1 人の人物の作成ではないこ とは明らかである。

注 18）太政類典：明治四年七月「工部省学校习設ク」（国立公文書館）。 工部省へ伺

自古国家ノ文明盛大ヨ成サント欲スル者皆其上下ヨシテ知識 7 備へ厚生利 用之途ニ出デシムル 要セザルナシ（中略）前書学校御取建之儀御英断 相成至速御無沙汰御座候様仕度候依之此断奉伺候也

工部省上申
工部学校御取設ノ儀二月見込ノ件建言仕候処右学校二付諸入費其外凡見込 可差出旨御達之趣二候処確定ノ規則八方今取調注二八候得共度々凡目論見 並諸入費凡積左之通二有之談

一、工部学校ハ小学校 英名 スクール

一、同大学校英名コウレージ

右二校他

一、小学校八少年生徒歳十六才以下ノ者 入校セシメ全ク西洋少年学校, 如ク教導ヨ為スベシ講堂図ノ如ク二棟二而生徒人員三百人ナルベシ

一、右小学校二而凡二年間ほど教導ヨ請而シテ後学力ノ検査ヨ経テ試程 超エル者成年寄宿所二入大学校二於而諸分科修行セシム大学校ノ寄宿所等 図ノ如シ

一、大学校二於テ修行中八諸工学技術二涉リ活物実地ノ修行ノ為仕学力 並業前上達ニテ検査习越エル者選挙ノ上洋行セシメ候事

一、大小学校寄宿所等凡略図ノ通少而造建諸入費八別紙二為調差出申候 尤傳習生徒月俸等八銘々ヨリ為差出候間官費二相立可申候事

凡目的右之通二有之候此談申上候也

幸未四月工部省

諸入費凡費

一、大学校一棟 金参萬七千武百八拾両

一、小学校等棟金武鿓五千八百四拾両

一、寄宿所式棟 全同行

一、諸教師居宅金壱萬五千両

一、大学校教師六人 壱人二付洋銀参百五拾弗此壱年洋銀式萬五千武百弗

一、同助教師 六人 壱人二付洋銀百五拾弗此壱年洋銀壱萬八百弗

一、小学校教師七人

$$
\text { 内 }
$$

上等壱人 月給武百弗

下等六人 月給百二十弗（中略）

年内八小学校御取建入費並小学校教師之内四名呼寄候入費) 御下渡相成 其余八追々相和紙相願候積二テ全ク年内御渡之分左の通（後略）

注 19) 大隈文書：十八日付大隈参議様 山尾庸三（早稲田大学古典籍総合デ 一タベース）。執筆年月不記載。

愚行之廉々御含迄二左二申上候

井上右鉱山専務

佐野右灯灯明台専務

小野右庶務専務

吉井右諸規則取調並二学校専務

山尾右造船製作専務

帰省中 松尾 右会計専務

未夕奉命前 福谷 右伝信掛専務

右之外有用之仁 二名

右エキスキューチンク専務壱名 同マネジャ専務壱名 但マネジャ者上 野を待て可也乎 壱名

右要地測量専務尤洋人壱名御雇入二而成年生徒数名手伝候八、修業二も 相成可然乎巳二灯明台之為の英政府より遣候仁ブラントンと不和ニて当時 御暇二相成居ソ之仁壱ヶ年程御試二而八如何乎且東京ヨリ神奈川辺測量を 手始めとして可也

・既往研究では本文書の執筆年月が明治 3 年 10 月と明治 4 年 4 月の 2 つ 分かれているが、各人物の任用時期を考えて柏原氏の後者を取る。

注 20）注 17）の文書で、山尾は工部省各課の長候補を挙げた後、測量事業の 必要性を説き、その専務に「ブラントンと不和ニて当時御餟ニ」していた 人物を当てたいと述べている。これはマクヴェイン以外に考えられない。

注 21）マクヴェイン日記は登明台掛辞職ととともに途絶えていたが、1872 年 1 月 1 日から再開寸る。前年を振り返って以下の記述から始まる。"Wrote to J. Cowan and to J. Craig by last mail. I think, recall my appointment to the Board of Works (Japanese Govt.) 13th Sept. 1871 - about three weeks afterwards was promoted to be Chief of the Imperial Survey Yozo. Yamao being appointed Chief Commissioner of Surveys \& Technical Education - about the same time George Eaton appointed assistant teacher 27 Oct./71. Henry Batson Joyner appointed assistant Engineer 17th Nov /71 (Transferred from Railway Section)

注 22）公文録：明治五年三月「工学校定則ノ概要」（国立公文書館）

注 23）公文録：明治五年二月「工学勧工都検ノ者御雇入他儀伺」（国立公文 書館)

注 24）灯台寮勤務時代のブラントンとマクヴェインの関係については、「R.H ブラントン：日本の灯台と横浜のまちづくりの父」（横浜開港資料館編, 1991）参照。ブラントンの来歴等について筆者も分担執筆した。 
注 25） Rev. McVean to Colin dated November 15, 1870, McVean Diary.

I would have written to Brown at once for a letter of introduction had you not said you were to call for said distinguished official \& introduce yourself. I find by your letter now to hand, though you had not done so - you still intended to go without waiting a formal introduction. Brown anticipated from his fine frank Scotch like character - you would if you found him, get a very cordial reception from him by merely mentioning his name tho' he told me there was a mystery about their not having heard from him which he could not understand. He had studied the Bible intently \& became convinced of the truth of christianity which he seemed to have embraced very cordially \& conscientiously but Brown had some fear this might have compromised him in the eyes of the Governing Powers of Japan, \& he advised me to say nothing about it - nor did I till now. But his friends in Glasgow were quite confident if he kept on good terms with the authorities he must have got into some important office. His own chief desire in coming to this Country was to acquire knowledge - which he might turn to account for the good of his own country. He had completely mastered the English language. as you ought to do theirs for your own interest.

・マクヴェインの父の質問に答えてブラウンは、山尾がグラスゴー滞在中キ リスト教をよく理解し、実践して暮らしていたが、日本の国情の中で自ら の信仰を告白することが難しいことは十分分かるので、それについては何 も質問す心゙きではないと助言した。また、山尾は来るべき日本のために知 識の修得に日々余念がなかったので、日本の新政府の中できっと活躍する ことは疑いないと結んでいる。

注 26) Olive Checkland: Britain's Encounter with Meiji Japan, Palgrave Schol, p.296, 1989.

注 27）注 2）エジンバラの土木事務所に 5 年勤めた後、イギリスの海軍水路 測量局に数年勤めたことがあった。この時の人脈が日本の測量司立ち上げ に大いに役に立ったと考えられる。

注 28) Thomas Constable (1812 1882) は、Encyclopædia Britannicaの版権を持 つスコットランドの大出版社 Archibald Constable（1774 1827）の長男とし て生まれ、父の事業を継ぐと供に、Royal Society of Edinburgh フェローとし てスコットランド文芸界でも活躍した。ルイス・ゴードンの回想録以外に、 ボアンヴィルの父のものも出版している。Thomas Constable: Memoirs of the Rev. Charles Alfred Chastel de Boinville", Edinburgh、1880.

注 29) Archibald Campbell Douglas (1820 1910) は、グラスゴーの聖職者の家 に生まれ、グラスゴー大学で哲学を学ぶ。John Thomas Rocheadのもとで建 築家修業を行い、独立してからはJohn James Stevenson や James Sellars とパ ートナーシップを組み、19 世紀後半のスコットランドを代表する建築家。

注 30) Thomas Constable: Remains of Alexander Cowan Consisting of His Verses and Extracts from His Correspondence and Journals, T. and A. Constable, Edinburgh, 1839.

注 31) David Stevenson and Thomas Constable: Memoir of Lewis D.B. Gordon, F.R.S.E. Late Regius Professor of Civil Engineering and Mechanics in the University of Glasgow, T. and A. Constable, Edinburgh, 1877.

注 32）注 30） pp. 186 190

Letter from Mr. Matheson, Hampsrad, 20 January 1877.

My Dear Miss Gordon, - Having had charge of some of the first students sent to this country from Japan many years ago, I was requested in 1872 by one of the number, who had become Minister of Public Works, to assist the Government to found at Yeddo a College of Civil and Mechanical Engineering. I was to select the professor, fix the scale of their salaries, arrange a programme of studies, and procure all the necessary books and materials required for an institution which was designed to train a large body of Japanese youths for the services of their country in connection with public works. The commission was felt by me to be a most difficult and responsible one, but as it was conveyed in the most generous terms, expressing unbounded confidence in my self, I resolved to set about its execution. I knew that there was one friend to whom I could apply with the certainty that he would give me good advice, and I lost no time in driving over to Totteridge to lay the matter before your dear brother. He gave me the encouragement of which I stood in need; and as the first thing was to obtain a man who could take the position of Principal, to whom the Government wished to give a good deal of authority, he recommended my communicating with the late Professor Macquorn Rankine, of Glasgow University, his own successor in the Chair of which he was the first occupant. That distinguished man was laid aside at the time by the illness of which he soon afterwards died, but he sent me several names, among them that of Mr. Henry Dyer, a young man of twenty-four, who had passed through his collage course with much distinction (後略).

注 33）参考文献 2) 舊工部大学校史料, 49 頁。同書 48 頁の「工学寮とマセ ソン商館ノ関係」と題する田辺朔郎が伊藤博文から聞き出した話しと合致 する。

注 34）久米邦武: 米欧回覧実記 2 イギリス編、慶應義塾大学出版会、2008 年、234 257 頁。 Roger G. Hipkin ed.: An Account of Two Visits to the Valleyfield Mills of Alexander Cowan \& Sons Ltd: The Iwakura Embassy in October 1872 - Frederick Catcheside in March 1881, Penicuik Community Trust, 2009.

注 35）大隈文書：明治四年十月至五年九月 工部省経費概算書、明治 4 年 11 月（早稲田大学古典籍総合データベース）。

注 36) George Eaton は、C \& D 1871 では横浜の保険代理店 Hudson, Malcolm \& Co.に所属しており、マクヴェインにスカウトされたと考えられる。工部省 御雇契約終了後は広島の英語学校教師を勤めた。

注 37）Henry Baston Joyner (1839 84) は、鉄道寮に勤めていたところをマクヴ エインの勧誘で工部省工学寮・測量司に転属した（Obituary, Minutes of the Proceedings, Institute of Civil Engineers, Volume 79, Issue 1885, p.370, 1 January 1885)

注 38） James Marks は、ブラントンの灯台掛にいたところをマクヴェインの 勧誘で工部省工学寮・測量司に転属した。アンダーソンとウィルソンの出自 は不明。

注 39) Richard Oliver Rymer-Jones (1849 ??)は、キングス・カレッジの Prof. Thomas Rymer Jones の息子で、一年遅れて兄の Thomas Manson も工部省に 鉄道技師として雇われる。マクヴェインとの具体的関係は不詳。

注 40）マクヴェイン日記 1872 年 1 月から関連部分を抜粋する。

Monday 8 Jan, Joyner tracing design for Technical School for Mr Yamao. Self drawing teachers quarters

Tuesday 9 Jan, Joyner tracing - (school). Self drawing (single teachers quarters)

Wednesday 10 Jan, Joyner finished tracing of design for Tech. School. Self drawing teachers quarters.

Wednesday 17 Jan, Joyner ill at home, Self drawing teachers quarters. Mr Yamao made Vice Minister of Public Works

Thursday 18 Jan, Self drawing teachers quarters

Friday 19 Jan, Self Do Do, ordered chest of drawers and rack for plans

Saturday 20 Jan, Self Do Do. Mr Yamao at the office - spoke to him about employing Mr. Jones - agreed -. So - as to Marks \& Anderson and if possible Wilson for the survey -

Monday 22 Jan, Self finished drawing single teachers quarters. Joyner back working drawing of boys quarters, ordered stone as specimen for office -

注 41) McVean Diary 1872.

Tuesday 23 Apr. P.M.S. Despatched letter to Mr Sameshima to London enclosing draft of agreement to be signed by assists at Japanese Legation - also draft for $\$ 8,000$ to pay for passages \& $\mathrm{c}$ - sent letter to Sharban with lists of Instruments \&c and a note to Cheesman offering appointment - $\underline{\text { Sharban }}$ to purchase Instruments Wrote to Campbell Douglas - asking him to appoint one teacher of surveying, one architect and a draftsman - wrote to Como Innes enclosing Draft \$2000, and copy of agreements, asked him to telegraph receipt - duplicates to be sent French mail. 中弁務使としてロンドンに駐在していた鮫島尚信にシャボーとチーズマン の採用手続きを、またキャンベル・ダグラスには測量教師 1 名、建築家 1 名、製図工 1 名の紹介を頼んだ。

注 42) Henry Scharbauは、マクヴェイン宛 1872 年 7 月 12 日付手紙では海軍 水路測量部（Hydrography Department, Admiralty）所属となっている。

注 43) Charles Alfred Castel de Boinville, 1850 97, Obituary RIBA Journal vol.4, 1897. このボアンヴィルの死亡者略歴は、キャンベル・ダグラスによって 執筆されたもので、ボアンヴィルが普仏戦争後のフランスを逃れてイギリ スに戻り、エジンバラのカンスタブルの紹介でダグタスのもとで働くよう になったこと、また、明治政府に雇われていたマクヴェインにさまざまな 便宜を図った事が述べられている。マクヴェイン日記から、1872 年 12 月 26 日に到着し、年が明けて教師館の設計と工事監理、加えて鉄道寮宿舎や 勧工寮建物の設計などをやっていたことが分かる。注 56）参照。

注 44）参考文献 6）工部省沿革報告，792 頁。同様なことが、参考文献 5）『明 治工業史 建築編』、18 頁にも述べられている。

注 45）Fig.7 の英文キャプションは、マクヴェインの日本写真帳 99 頁に掲載 されているもので、ジョイナーの設計となっているが、実際は「工部省学 校习設ク」に付された略図面をもとに実施図面を作成したと考えられる。

注 46) McVean Diary 1872. 
Monday 26 Feb. Self Joyner Jones \& Eaton - Lists of articles required from home for Tokei Technical School.

Tuesday $27 \mathrm{Feb}$. all as above - Mr Murata and self - left for Yokohama at 5 P.M. - with an order for $\$ 14000$, estimated half cost of material required - lodged same in the C.M. Bank as security for payment of the whole - and I wrote a letter to Campbell Douglas, 266 St Vincent St Glasgow - requesting him to execute the order $-5 \mathrm{pc}$. allowed on same.

Wednesday 28 Feb. at the C. M. Bank all forenoon finishing letters - and posting them - Order for goods and fittings required for Technical School Tokei despatched per American mail at noon - addressed to Campbell Douglas - with letter requesting him to procure and forward same to this Post without delay via Suez Canal

・ダグラスに複数回資材調達を依頼したが、注文リストは発見されていない。

注 47) McVean Diary 1872 .

Wednesday 20 Mar. Two $100 \mathrm{ft}$ measuring tapes came from Lane \& Crawford also pencils for office - Taki Japanese carpenter come - ordered 30 piculs Hoop Iron from Hudson Malm \& Co. Joyner as above. gave Anderson sizes of roof timber for school Ho

注 48) McVean Diary 1872.

Monday 25 Mar. When I saw Mr Yamao last - on the 21 st inst.- sanctioned a little additional expenditure on the buildings. I also suggested the necessity of providing temporary quarters for the Teachers of Kogakurio - to arrive next August as the buildings can not be completed so soon as at first intended -. Joyner - drawing of S. Ho - doors \& windows. Cartman's temporary appointment sanctioned.

Tuesday 26 Mar. Writing report on survey. Joyner making out lists of Instruments \& books \&c - Despatched per American Mail tracing of Clock turret and Library roof also - Duplicate of alterations in order. Cartman shot himself through the hand - Dr says he must lay up for 10 days -

· 3 月 25 日付けで、工学寮教師の宿舎建設が遅れており、来年 8 月の到着 には間に合わないので、臨時の宿舎を用意するように山尾に進言した。ま た、3月 26 日にジョイナーは装置と図書の注文リストを作り、時計台と図 書館の屋根の図面を発送したと述べられている。

注 49）参考文献 2）舊工部大学校史料，52 頁。

自英国招致之教室号有之目途ヨリ八凡二三箇月延引可致見込二有之候

(後略) 壬申四月三十日 工部省少輔 山尾庸三

注 50) Whitfield and Dowson, Engineer and etc. Yokohama, C \& D 1872. 来歴に ついては、堀勇良著：外国人建築家の系譜（日本の美術 8,86 頁，2003 に 詳しい。

注 51) McVean Diary 1873 .

Friday 14 Feb. Mullions of Boys quarters Kogaku to be in brick walls, to be reduced to 14 in thick - from 18 in -

注 52） 1872 年 3 月末から 4 月にかけてのマクヴェン日記は以下の通りある。 Friday 29 Mar. Mr Yamao \& Mr Sano - afternoon - talking over the building and survey arrangements - complained of expense of timber - but decided it should be of the best where necessary - decided on sending for surveyors - [Jas s] \&c \&c by next mail - wished for estimate of cost of two portable saw mills with Engine decided on having Meteorological Instruments.

Saturday 30 Mar. Anderson reports - none of the timber is what he chose - but all of inferior quality - reported same to Matsui - suggested sending to Yokohama for 50 good carpenters - sanctioned the purchase of three Instrument [cases ] for Jones class - ordered 3000 bags of lime to be brought [b/8] [sedays] -. Informed Matsui shingle \&c for concrete for school Ho - not arriving quickly enough -.

Monday 1 Apr. Saw Yamao at Cobusho - he agreed that I should go home with a commission from Government to procure large Instruments for survey \&c. wishes surveyors sent for by next mail - one teacher one Architect - four surveyors and a draftsman - form of agreement to be drawn up him - Spoke to him about Wheeler appointment

Tuesday 2 Apr. Afternoon went to Yokohama saw Shand about money for passages of new assts from England and India - Bank agrees to advance the money without a deposit on the seal of B of W.

Wednesday 3 Apr. Saw Mr Yamao at the Railway station - he wishes assistants agreements to be signed at the Japanese Embassy in London - brought chain and arrows for office - Returned in the evening with Mr Yamao - great fire burning in Tokei - Cobusho \& large Hotel burned
Thursday 4 Apr. Went to examine and report upon extent of fire - and as to making a survey of the ground - in order to enable Tokei $[F \ldots]$ to lay out new streets - \&c. found the burned quarter to extend about a mile and a half long by half mile wide - from within the $2 \mathrm{~d}$ moat to Tsukidji - from 20 to 30,000 people reported to have been burned out -

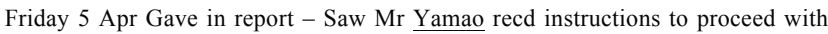
the [survey/money?] - survey to be finished in 7 day. Adjusting instruments \&c 3 P.M. Joyner - made a beginning at Wadakuragomon.

Saturday 6 Apr. 6 a.m. Joyner - Jones \& self at survey till 6 p.m.

Sunday 7 Apr. Joyner Jones - Wilson from Benten - self \& two Japanese - survey Monday 8 Apr. 6 p.m. Smedley arrived at Tsukidji. Joyner Jones self - plotting Wilson \& Japanese surveying - paper spoiled in mounting -. Telegraphed for

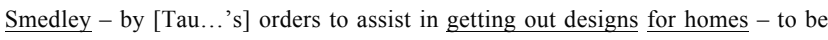
built in place of those burned -. Telegraphed for protractor 50 sheets d. paper one roll tracing paper - and pencils from Lane \& Crawford.

Tuesday 9 Apr. Mr Smedley designing homes for the people of Tokei burned out by the great fire-Field work of survey finished except a few measurements to be done when the street is plotted - Yamao went to Osaca by last mail.

注 53）John Smedley (1841 1903)は、シドニーの画家兼装飾家のサミュエル. スメドレーのもとに生まれ、幼少の頃から絵画とデザインに秀でたものが あり、シドニーで建築家修業をした後、香港のストーリー建築・土木事務所 に勤務。上海を経て神戸で仕事をしていたところ、1872 年、マクヴェイン に呼ばれて銀座復興計画作りに従事し、その後、横浜で建築・土木事務所 を開設した。Joan Kerr ed:: The Dictionary of Australian Artist: Painters, Sketchers, and Engravers, Oxford University Press, 1993.

注 54）村田文夫は広島藩の藩医の家に生まれ、幕末にグラバーの斡旋でイギ リスに密航し、スコットランドで 2 年近くを過ごす。山尾とほぼ同じ時期 に帰国し、広島藩洋学教授をしばらく勤めた後、明治 3 年民部省に出仕。

工部省発足とともに工学寮・測量司に転属し、その間に Cottage Building (C. B. Allen, 1864）を『西洋家屋雛形』として翻訳する（藤田治彦：明治 5 年 刊『西洋家作雛形』の建築用語, 侍兼山論叢 美学編, 1999 年, 1 24 頁）。 マクヴェインは”Cottage Buildings”を所有しており、銀座地区復興計画作成 の際に翻訳させたと考えられる。マクヴェインは、日記によれば大和屋敷 の外国人住宅以外に、山尾庸三や三条実美の公邸を設計している。

注 55）マクヴェインの報告書は以下の大隈文庫に収められている。

- 大隈文庫：イ14 A3907 而震耐火家屋建築二関スル建言書 佐野工部大丞 宛 / 工部省測量首官マコビーン, 明治 5 年 4 月 19 日（早稲田大学古典籍 総合データベース)

-大隈文庫：イ $14 \mathrm{~A} 3908$ 東京府下市街及家屋造作二関スル至当ノ定則 / 工 部省測量司マコビーン, 明治 5 年 4 月 19 日（早稲田大学古典籍総合データ ベース)

注 56）藤森照信：明治の東京計画，岩波書店，1982。

注 57） 1872 年から 75 年のマクヴェイン日記によれば、ウォートルスたちと しばしば会食したことが述べられており、良好な関係であったようだ。 McVean Diary 1872: Friday Jul 5. Fine day, beginning to get hot. In the evening Mrs Godfrey, Captain \& Mrs S. Mr Waters and Mr Spilling.

注 58）「工学寮及測量司分課処務規定」（明治 5 年 6 月 26 日布達）の中で は、「造営課（測量司ニワ之ヨ除ク）這科大小学校並教師館生徒館新規建 築中之ヨ置ク」となっているが、「除ク」は「置ク」の誤植と考えられる。 後年も、「明治六年十月十三日測量司习分離シ馬場先門内ノ舊集議院二移 置シ、而シテ工学寮ノ建築事務八総テ同司へ委任スベキ旨山尾工部大輔ヨ リ林工学助及測量正内裏林田工学権助へ達セラレタリ」とあるように、工 学寮の建築業務は測量司に任されていた。マクヴェイン日記では、測量司 は他に勧工寮の建物や鉄道寮の宿舎などの営繥を行っていたことがわかる。 Saturday 6 Jul. 1872. Plan of Kwankorio grounds finished [....] tracing Tuesday 18 Feb. 1873. Mr Grioye C.C. of Railways called to ask if Mr Di Boinville could make drawings for new railway quarters to be built near Yamato Yashiki.

注 59）公文録：明治 5 年 11 月「測量司御雇仏人ボアンフール来着届」 立公文書館)

注 60）参考文献 2）工部省沿革報告，31 頁。「明治七年一月九日測量司 7 内 務省二属セラレル」。また、同 32 頁では、「二十二日内務省土木寮所管， 営繕事務习本省二割属セラル、二十八日ニ至テ製作寮其事務习継承シ而シ テ寮中二営䋨課 置キ二月八日ニ至テ本省会計局ノ営繥科 合併ス」とあ り、測量、土木、営繕の部門は大変な改組を経験している。 


\section{RECONSIDERATION OF COMMENCEMENT OF ENGINEERING EDUCATION UNDER THE MINISTRY OF PUBLIC WORKS IN THE MEIJI JAPAN}

Contribution of Yozo Yamao and C.A. McVean to conceptualization and realization

\section{Hideo IZUMIDA*}

* Dept. of Architecture and Civil Engineering, Toyohashi University of Technology, Dr.Eng.

\section{Idea of setting up of Engineering Education Division}

Edmund Morel, a British civil engineer hired as chief engineer for the railway construction by the early Meiji government, proposed to found the department of public works, which was to consist of execution, accounts and education divisions. He insisted on importance of the engineering education to train young Japanese at school and college as various fields of engineers for that ministry. But when the government accepted the proposal through Hirobumi Ito (伊藤博文), and agreed to found the Ministry of the Public Works in November 13, 1870, education division was ignored. Morel and Yozo Yamao (山尾庸三), a vice minister endeavoured to realize the education division.

They prepared a scheme of foundation of institution, fixing the structure and capacity, and estimating construction cost of the buildings and salary of the hired teaching staff in May 1871. The school would accept 300 students and give them 2 years fundamental knowledge, and those who acquired excellent grades would proceed to the college, where they would learn both theory and practice of professional subjects by 6 teachers and 6 assistant teachers for 2 years. One teacher and one assistant teacher might form a discipline, and take the responsibility for that department respectively. Sketch plans of the school and student dormitory were prepared and attached to the scheme. Morel and Yamao set up this scheme, expropriating a daimyo's land for the institution premises, and asking someone to hire these teaching staff.

2. Teaching Staff for the Institution

It is widely believed that Hugh Matheson made hearty contribution to the Meiji Japan, when he was commissioned by Ito in August 1872 at London to hire that teaching staff. Matheson asked it firstly to Lewis Gordon, one of his friends as well as retired professor of civil engineering at Glasgow University, then to Prof. William Rankine of same university, who recommended Henry Dyer as principal of the institution together with other 6 staff. However, more than one year before Ito met Matheson, Morel and Yamao asked someone to send that teaching staff to Japan, and assured that they would arrive at Japan in August 1872 before opening of the school as the Outline of the Institution (released in November 1871) mentioned. But due to the delay of recruitment of teachers and construction of school buildings, it could not be open on schedule.

3. Kogaku-Ryo and Sokuryou-Shi

Kobu-Sho (工部省) or the Ministry of the Public Works was officially organized in September 291871 or August 14 th. Meiji 4 with 11 divisions including Kogaku-Ryo (工学寮) or education division and Sokuryou-Shi (測量司) or survey division. Kogaku-Ryo was intended to manage several training programmes of Japanese engineers at its institution and foreign institution, while the Sokuryou-Shi was to take responsibility for surveying and mapping of national land and sea. Yamao was appointed as head of both divisions, and hired Colin Alexander McVean as a chief surveyor to the Sokuryou-Shi. As there was no public works and buildings divisions, McVean played essential role not only in surveying and mapping works but also in building construction works including the engineering school buildings. 